\title{
Secondary metabolites from plants inhibiting $A B C$ transporters and reversing resistance of cancer cells and microbes to cytotoxic and antimicrobial agents
}

\author{
Michael Wink ${ }^{1}$, Mohamed L. Ashour ${ }^{2}$ and Mahmoud Zaki El-Readi ${ }^{1,3}$ \\ 1 Institute of Pharmacy and Molecular Biotechnology, Heidelberg University, Heidelberg, Germany \\ ${ }^{2}$ Department of Pharmacognosy, Faculty of Pharmacy, Ain Shams University, Cairo, Egypt \\ ${ }^{3}$ Department of Biochemistry, Faculty of Pharmacy, Al-Azhar University, Assiut, Egypt
}

\section{Edited by:}

Bruce C. Campbell, Western Regional Research Centre, USA

\section{Reviewed by:}

Jon Y. Takemoto, Utah State

University, USA

Dominique Sanglard, University of

Lausanne and University Hospital

Center, Switzerland

Slawomir Milewski, Gdansk

University of Technology, Poland

${ }^{*}$ Correspondence:

Michael Wink, Institute of Pharmacy and Molecular Biotechnology,

Heidelberg University, INF 263,

D-69221 Heidelberg, Germany.

e-mail:wink@uni-hd.de
Fungal, bacterial, and cancer cells can develop resistance against antifungal, antibacterial, or anticancer agents. Mechanisms of resistance are complex and often multifactorial. Mechanisms include: (1) Activation of ATP-binding cassette (ABC) transporters, such as P-gp, which pump out lipophilic compounds that have entered a cell, (2) Activation of cytochrome p450 oxidases which can oxidize lipophilic agents to make them more hydrophilic and accessible for conjugation reaction with glucuronic acid, sulfate, or amino acids, and (3) Activation of glutathione transferase, which can conjugate xenobiotics. This review summarizes the evidence that secondary metabolites (SM) of plants, such as alkaloids, phenolics, and terpenoids can interfere with $A B C$ transporters in cancer cells, parasites, bacteria, and fungi. Among the active natural products several lipophilic terpenoids [monoterpenes, diterpenes, triterpenes (including saponins), steroids (including cardiac glycosides), and tetraterpenes] but also some alkaloids (isoquinoline, protoberberine, quinoline, indole, monoterpene indole, and steroidal alkaloids) function probably as competitive inhibitors of P-gp, multiple resistance-associated protein 1, and Breast cancer resistance protein in cancer cells, or efflux pumps in bacteria (NorA) and fungi. More polar phenolics (phenolic acids, flavonoids, catechins, chalcones, xanthones, stilbenes, anthocyanins, tannins, anthraquinones, and naphthoquinones) directly inhibit proteins forming several hydrogen and ionic bonds and thus disturbing the 3D structure of the transporters. The natural products may be interesting in medicine or agriculture as they can enhance the activity of active chemotherapeutics or pesticides or even reverse multidrug resistance, at least partially, of adapted and resistant cells. If these SM are applied in combination with a cytotoxic or antimicrobial agent, they may reverse resistance in a synergistic fashion.

Keywords: ABC transporter, P-gp, MDR, MRP1, secondary metabolites, review

\section{INTRODUCTION}

\section{EVOLUTIONARY AND ECOLOGICAL BACKGROUND}

Plants are sessile organisms which cannot run away when attacked by an herbivore nor do they have an immune system to combat infesting parasites, bacteria, fungi, or viruses. From early days of the evolution of land plants they had to cope with these environmental challenges. Plants developed a number of mechanical traits, such as resistant epidermal and bark tissues but also spines and thorns as defense tools. In addition, plants evolved a high diversity of defense chemicals, the so-called secondary metabolites (SM; Table 1). Besides defense, some SM function as signal compounds or protect against oxidative or UV stress (Wink, 1988, 2003, 2008b, 2010a,b).

The structures of SM have been optimized during evolution in such a way that they can interfere with molecular targets

Abbreviations: ABC, ATP-binding cassette; BCRP, breast cancer resistance protein; MDR, multidrug resistance; MRP1, multidrug resistance-associate protein; P-gp, P-glycoprotein. in herbivores and microbes. The main group of targets include (1) proteins, (2) DNA, RNA, and (3) the biomembrane (Wink, 2008a,b; Wink and Schimmer, 2010). Neuronal signal transduction is a central and specific target in animals and many SM, especially alkaloids and amines are directed toward it (Wink, 1993, 2000). SM which interfere with proteins, such as polyphenols, biomembranes (saponins and other lipophilic terpenoids), or DNA (alkylating or intercalating mutagens) affect a wider range of organisms, including animals and microbes. In general, membrane and DNA active SM have cytotoxic properties. Affected cells usually undergo apoptosis (Wink, 2007). Several SM interfere with the neuronal signal transduction in animals and are thus potent neurotoxins (Wink, 1993, 2000).

A large number of SM have lipophilic properties which enable them to readily pass biomembranes in target organisms by simple diffusion. These SM are also dangerous for the producing plants. Therefore, they are usually stored in dead tissue away from living cells, such as resin ducts, oil cells, trichomes, or cuticles (Wink, 2010b). The absorption of polar SM is usually slower or does not 
Table 1 | Structural types of secondary metabolites and known structures.

\begin{tabular}{lr} 
Class & Number of structures \\
\hline WITH NITROGEN & 21000 \\
Alkaloids & 700 \\
Non-protein amino acids (NPAA) & 100 \\
Amines & 60 \\
Cyanogenic glucosides & 100 \\
Glucosinolates & 150 \\
Alkamides & 2000 \\
Lectins, peptides & \\
WITHOUT NITROGEN & 2500 \\
Monoterpenes (incl. iridoids) & 5000 \\
Sesquiterpenes & 2500 \\
Diterpenes & 5000 \\
Triterpenes, steroids, saponins & 500 \\
Tetraterpenes & 2000 \\
Phenylpropanoids, phenolic acids, & \\
coumarins, lignans & 10000 \\
Flavonoids, isoflavonoids, anthocyanins, & \\
stilbenoids, tannins, xanthones & 1500 \\
Polyacetylenes, fatty acids, waxes & 750 \\
Polyketides (quinones, anthraquinones) & 400 \\
Carbohydrates, organic acids & \\
\hline
\end{tabular}

take place at all, with the exception of SM that can use transporters for sugars or amino acids or endocytosis as a kind of "stowaway." Furthermore, SM usually occur in complex mixtures which may contain SM (such as saponins) that can facilitate the uptake of polar SM (Hebestreit and Melzig, 2003).

\section{THE RESPONSE OF HERBIVORES AND PATHOGENS AGAINST PLANT DEFENSE CHEMICALS}

In the evolutionary arms race herbivores and microbes evolved mechanisms to avoid or inactivate the defense chemistry of plants. Mechanisms of resistance in animals and humans are complex and often multifactorial. Mechanisms include: (1) Activation of ATPbinding cassette $(\mathrm{ABC})$ transporters, such as $\mathrm{p}$-gp, which pump out lipophilic compounds that have entered a cell, (2) activation of cytochrome p450 oxidases (CYP) which can oxidize lipophilic agents to make them more hydrophilic and accessible for conjugation reaction with glucuronic acid, sulfate, or amino acids, and (3) activation of glutathione transferase (GST), which can conjugate xenobiotics with glutathione. The reactions of CYP, GST, and conjugation are well known in pharmacology and categorized as phase I and phase II reactions. These reactions are important in the metabolism of medicinal drugs and toxins. This evolutionary history also applies for humans which enables us to metabolize a large number of xenobiotics.

In phase I, a lipophilic SM is made more hydrophilic by introducing hydroxyl groups. This reaction is catalyzed by CYP and CYP1A1, CYP1A2, CYP3A4, and CYP2D6 are the most important enzymes. Furthermore, these CYP can cleave $N$-methyl, $O$-methyl, or methylene groups in order to obtain a more hydrophilic or better accessible substrate (Guengerich, 2001). In the human genome, about 57 active CYP genes are known (Ingelman-Sundberg and Gomez, 2010). A substantial polymorphism of CYPs exists which enables them to metabolize a wide range of xenobiotics. The regulation of the corresponding genes is only partly known. The genes encoding these enzymes, which occur in intestinal epithelia and in the liver, are inducible by SM that have entered the body. In phase II, the hydroxylated xenobiotics are conjugated with polar molecules, such as glutathione, sulfate, or glucuronic acid. These conjugates are eliminated via the kidneys and urine. That means, on exposure to lipophilic SM, genes which encode these enzymes are often induced and that activation can inactivate the toxins. Several SM carry methylenedioxy groups on their phenolic rings, such as in the isoquinoline alkaloids berberine and hydrastine, which are assumed to be inhibitors of CYP (Wink, 2007). Alkaloids which can inhibit CYP have been summarized by Wink (2007).

Resistance mechanisms in bacterial pathogens are even more evident because several pathogens already have evolved resistance against medicinally used antibiotics. The main mechanisms include:

- Direct inactivation of the antibiotic, e.g., by cleavage of the beta-lactam ring of penicillin by beta-lactams or acetylation, methylation of other antibiotics

- Target site modification: molecular change of the target molecule (proteins, rRNA) in such a way that the antibiotic cannot bind any longer

- Bypass or alteration of metabolic pathways in cases where an antibiotic blocks a pathway (e.g., as for sulfonamides)

- Prevention of drug uptake

- Export out of the cell by ABC transporters so that the intracellular concentration of an antibiotic (e.g., tetracycline) are reduced. In Bacteria, this is one of several factors responsible for multidrug resistance (MDR).

\section{ABC TRANSPORTER}

Resistance against defense chemicals can be obtained through the expression of $\mathrm{ABC}$ transporters that are present in most cells and organisms. They are especially active in epithelia of intestinal, liver, kidney, and endothelia (Twentyman and Bleehen, 1991; Nielsen and Skovsgaard, 1992; Nooter and Stoter, 1996; Steinbach et al., 2002; You and Morris, 2007).

Three types of $\mathrm{ABC}$ transporters have been studied in detail:

1. P-glycoprotein (P-gp; molecular weight $170 \mathrm{kD}$ ) or MDR1 protein (multiple drug resistance protein) was the first cloned $\mathrm{ABC}$ transporter. It is encoded by the $A B C B 1$ gene. $\mathrm{P}$-gp is composed of two similar moieties and each half contains one transmembrane and one ATP-binding domain. P-gp is an efflux pump directed to the gut lumen. The substrate molecules bind to transmembrane domains and then are exported to extracellular space, driven by the energy of ATP hydrolysis. A wide range of lipophilic chemotherapeutical agents, such as anthracenes, anthracyclines, epipodophyllotoxins, taxanes, and Vinca alkaloids, which can enter tumor cells by free diffusion, are substrates of P-gp and can be extruded by the transporter (Loo and Clarke, 2005). 
2. Multiple resistance-associated protein $1(\mathrm{MRP} 1 ; 190 \mathrm{kD})$ is encoded by the $A B C C 1$ gene. MRP1 transports drugs conjugated to glutathione (GSH), and also unmodified therapeutics in the presence of GSH (van der Kolk et al., 1999). MRP1 is structurally similar to P-gp, and can expel anthracenedione, anthracycline, epipodophyllotoxin, Vinca alkaloids, etc. (Wijnholds et al., 2000).

3. Breast cancer resistance protein (BCRP; $72 \mathrm{kD}$ ) is the product of the $A B C G 2$ gene. It has one transmembrane domain and one ATP-binding domain and only functions after dimerization. BCRP confers resistance to doxorubicin, camptothecin, and mitoxantrone (Ambudkar et al., 1999; Schinkel and Jonker, 2003; Mao and Unadkat, 2005; Krishnamurthy and Schuetz, 2006).

Breast cancer resistance protein and P-gp are highly expressed at the apical membrane of blood-brain barrier (BBB), placenta, liver, intestine, and other organs (Schinkel and Jonker, 2003). These ATP-driven transporters can pump lipophilic compounds out of the cell, either back to the gut lumen or into the blood system, thus reducing the intracellular concentration of potentially toxic compounds.

ATP-binding cassette transporters are also important at the BBB. The BBB only allows the entry of small lipophilic substances by passive diffusion. However, the uptake of lipophilic compounds in the brain is relatively low due to the high activity of P-gp, MRP, and organic anion transporting polypeptides (OATPs). These transporters catalyze a rapid efflux of lipophilic xenobiotics from the CNS (Elsinga et al., 2004; Mahringer and Fricker, 2010).

Multidrug resistance was discovered during chemotherapy of cancer patients who developed resistance against a cytotoxic drug. It transpired that the tumor cells were able to pump out the lipophilic alkaloids (such as Vinca alkaloids, taxanes, and anthracycline derivatives) at almost the same speed as they were entering the tumor cells. Activated cells became resistant to vincristine but also to several other lipophilic drugs. This means that a cross-resistance or MDR had occurred. As a consequence, a major obstacle to the successful chemotherapy of tumors is MDR. Upon exposure to xenobiotics MDR genes can become upregulated. Overexpressed $\mathrm{ABC}$ transporters (P-gp, MRP1, or BCRP) can mediate resistance of tumor cells against a variety of anticancer drugs (Schinkel and Jonker, 2003). This phenomenon is called MDR, which is one of the most important reasons of chemotherapy failure (Gottesman, 2002).

Several of human protozoal parasites (Plasmodium, Leishmania, Trypanosoma) can develop resistance against prophylactic and therapeutic agents, such as quinolines, naphthoquinones, sesquiterpene lactones, and others. The underlying mechanism includes membrane glycoproteins that are orthologous to human P-gp. These ABC transporters can also be induced and activated.

ATP-binding cassette transporters are also present in bacteria and fungi in which they confer resistance to antibiotics and fungicidal compounds (Steffens et al., 1996). A medicinally important issue is the increasing resistance of bacteria toward antibiotics, and $\mathrm{ABC}$ transporters can be involved in bacterial MDR (besides other mechanisms discussed above). Apparently, ABC transporters are an old invention of nature, which occur from E. coli to Homo sapiens.

\section{OVERCOMING RESISTANCE CAUSED BY ABC TRANSPORTERS}

Multidrug resistance reversal agents are also called chemosensitizers or modulators. They can inhibit the efflux activity of transporters and other relevant MDR targets (see above); in consequence they can potentiate cytotoxicity, and are therefore important alternatives to overcome MDR (Watanabe et al., 1995; Dantzig et al., 1996; Robert and Jarry, 2003).

Multi-resistant tumor cells frequently express different $\mathrm{ABC}$ transporters simultaneously, e.g., P-gp, MRP1, BCRP, and others (Annereau et al., 2004; Gillet et al., 2004). Because the substrate spectra of $\mathrm{ABC}$ transporters only partly overlap, co-expression of transporters might produce more diverse resistance profiles than those of any one member alone. Thus broad-spectrum reversal agents are needed and some compounds exhibit this property (Hyafil et al., 1993; Maliepaard et al., 2001; Brooks et al., 2003).

A number of natural or synthetic compounds have been discovered that can inhibit P-gp and re-sensitize resistant tumor cells in vitro (Chauffert et al., 1990; Genne et al., 1992; He and Liu, 2002; Wink, 2007). Although these agents work successfully in some patients, most results of clinical trials were disappointing (Solary et al., 2000; Dantzig et al., 2001). Some of these reversal agents did not work in vivo or some had too severe side effects. Therefore, new and better reversal agents are still needed.

Most modulators of $\mathrm{ABC}$ transporters act by binding to membrane transport proteins (especially P-gp, MRP1, and BCRP) as competitive inhibitors, or by indirect mechanisms related to phosphorylation of the transport proteins, or the expression of the mdr1 and mrp1 genes. Other inhibitors not only act at the level of the transporter gene but influence their expression; for example, the alkaloid piperine lowered the expression levels of $A B C B 1$, $A B C C 1$, and $A B C G 2$ genes which encode P-gp, MRP1, and BCRP (Li et al., 2011b).

\section{INHIBITORS OF ABC TRANSPORTERS FROM PLANTS}

For this review we carried out a comprehensive literature research. Table 2 summarizes the search results for SM from plants, which can serve as $\mathrm{ABC}$ transporter substrates and might be useful in strategies to reverse drug resistance in cancer cells, fungi, and parasites. Compounds affecting other resistance mechanisms, which are important and which were discussed above, were not considered in this review.

Lipophilic SM, such as monoterpenes, diterpenes, triterpenes (including saponins), steroids (including cardiac glycosides), and tetraterpenes (carotenoids; Table 2) function as substrates for P-gp in cancer cells. The ABC transporter from fungi, AtrB (Andrade et al., 2000), or the NorA efflux pump in Staphylococcus aureus can also be affected (Smith et al., 2007). Because of their lipophilicity, these terpenoids most likely are substrates for P-gp and other ABC transporter. If administered as a chemosensitizer in combination with a cytotoxic agent they function as inhibitors competing for binding to the active side of the transporters. 
Table 2 | Secondary metabolites from plants that can inhibit P-gp, MRP1, BCRP, bacterial, and fungal ABC transporters.

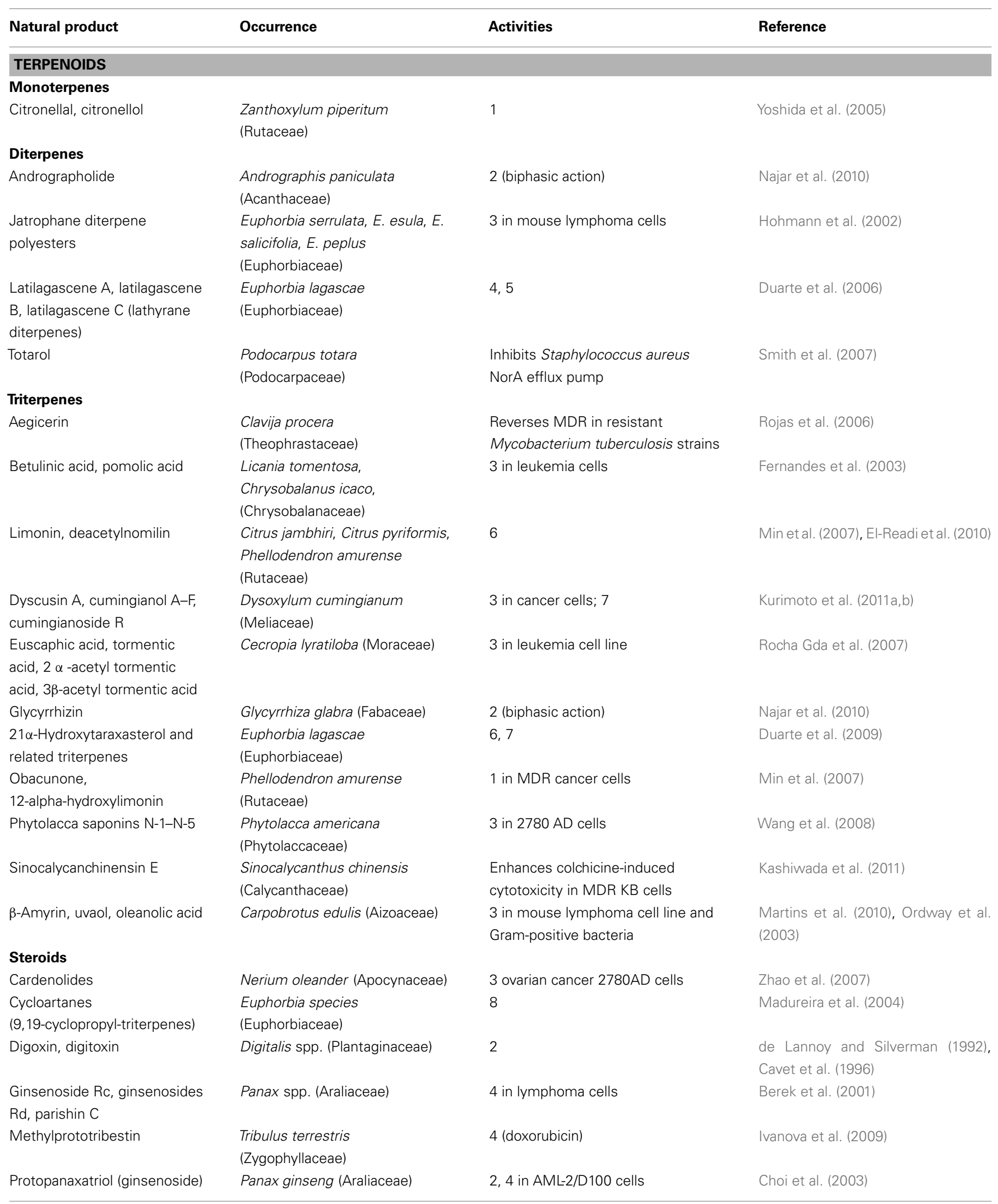


Table 2 | Continued

\begin{tabular}{llll}
\hline Natural product & Occurrence & Activities & Reference \\
\hline $\begin{array}{l}\text { Stigmasterol, } \\
\text {-sitosterol-O-glucoside }\end{array}$ & $\begin{array}{l}\text { Citrus jambhiri, Citrus pyriformis } \\
\text { (Rutaceae) }\end{array}$ & 1 in Caco2 and leukemia cells & El-Readi et al. (2010) \\
$\begin{array}{l}\text { Withaferin A } \\
\text { Tetraterpenes }\end{array}$ & Withania somnifera (Solanaceae) & 4 in K562/Adr cells & Suttana et al. (2010) \\
$\begin{array}{l}\text { Carotenoids (lycopene, } \\
\text { violaxanthin, and related } \\
\text { compounds) }\end{array}$ & $\begin{array}{l}\text { Capsicum annuum (Solanaceae); } \\
\text { Daucus carota spp. sativus }\end{array}$ & 1,9 & Molnar et al. (2004), Kars et al. (2008), \\
PHENOLCS & (Apiaceae) & Gyemant et al. (2006)
\end{tabular}

\section{PHENOLICS}

Phenyl propanoids

Chlorogenic acid

Coffea arabica (Rubiaceae) and

1

many plants

Curcumin,

Curcuma longa (Zingiberaceae)

1,5

tetrahydrocurcumin

Flavonoids, catechins, chalcones, xanthones, stilbenes, anthocyanins, and related polyphenols

Acacetin

Several families

Afrormosin, robinin,

amorphigenin

Ampelopsin

Apigenin,

Baicalein

Biochanin A

Calodenin $\mathrm{B}$, dihydrocalodenin

$\mathrm{B}$, and other dimeric

proanthocyanidins

Chrysin

Chrysosplenol-D,

chrysoplenetin

Cyanidin, callistephin,

pelargonin, ideanin, cyanin,

pelargonidin, and related

anthocyanidins

Daidzein

5,7-Dimethoxyflavone,

kaempferide

Diosmin

Ellagic acid, tannic acid

Epicatechin, epicatechin gallate, epigallocatechin, epigallocatechin gallate (EGCG)
Several Fabaceae

Hovenia dulcis (Rhamnaceae)

Several plants

Scutellaria baicalensis

(Lamiaceae)

Several families

Ochna macrocalyx (Ochnaceae)

Several species

Artemisia annua L. (Asteraceae)

Glycine max L. Merr. (Fabaceae), Aronia melanocarpa L.

(Rosaceae)

Several species of Fabaceae

Kaempferia parviflora

(Zingiberaceae)

Citrus spp. (Rutaceae)

Several species

Camellia sinensis (Theaceae); Carpobrotus edulis (Aizoaceae)
1, 10 in human erythrocytes and breast cancer cells

1,10

1,5 in K562/ADR cells

$1,4,9,10$ in MES-SA/DX5 cells; substrate for multidrug transporter in Plasmodium falciparum Substrate for Yorlp and Pdr5p transporters in yeast Saccharomyces cerevisiae 1, 9 Inhibit MDR in Staphylococcus aureus (RN4220, XU212, and SA-1199-B)

1, 2 (biphasic action), 9

Synergistic inhibition of MDR in Staphylococcus aureus

1

$1,9,10$

9 (in vitro and in vivo)

2

Inhibit an efflux pump in Acinetobacter baumannii and enhances antibiotic activity 1 in MCF-7/Adr and mouse lymphoma cell line; 9, 10; 3 in Gram-positive bacteria
Najar et al. (2010)

Zhou et al. (2004), Limtrakul et al. (2007), Hou et al. (2008), Lu et al. (2012)

Wesolowska et al. (2009)

Gyemant et al. (2005)

Ye et al. (2009)

Zhang et al. (2004), Leslie et al. (2001), Perez-Victoria et al. (1999), Wesolowska et al. (2009), Angelini et al. (2010) Kolaczkowski et al. (1998)

Chung et al. (2005), Zhang et al. (2004) Tang et al. (2003)

Molnár et al. (2008), Gyemant et al. (2005), Zhou et al. (2004), Zhang et al. (2004), Critchfield et al. (1994), de Wet et al. (2001)

Stermitz et al. (2002)

Molnár et al. (2008)

Chung et al. (2005), Zhang et al. (2004), Cooray et al. (2004)

An et al. (2011)

Yoo et al. (2007)

Chusri et al. (2009)

Martins et al. (2010), Zhang et al. (2004), Zhu et al. (2001), Gyemant et al. (2005), Mei et al. (2004), Wei et al. (2003) 
Table 2 | Continued

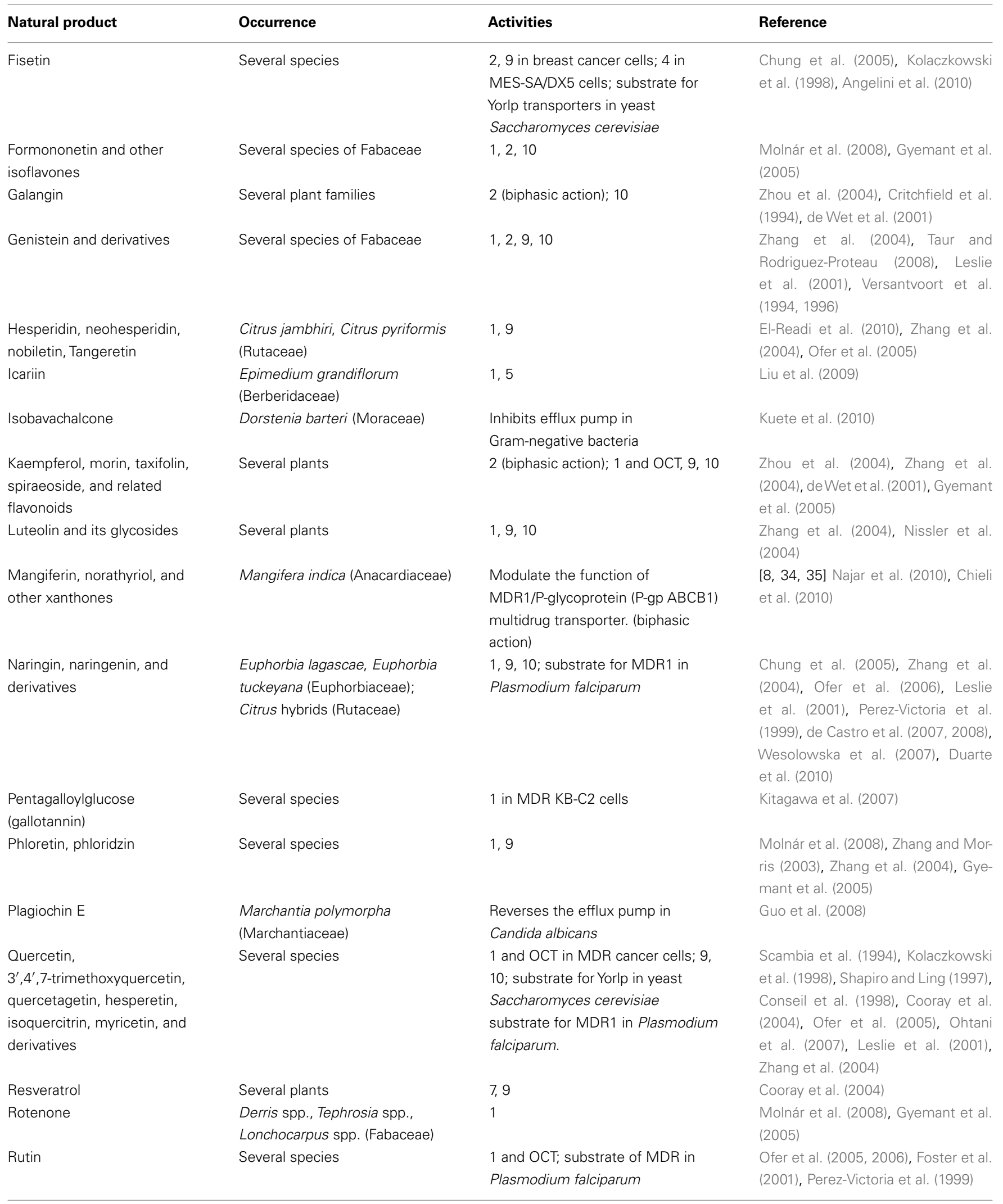

(Continued) 
Table 2 | Continued

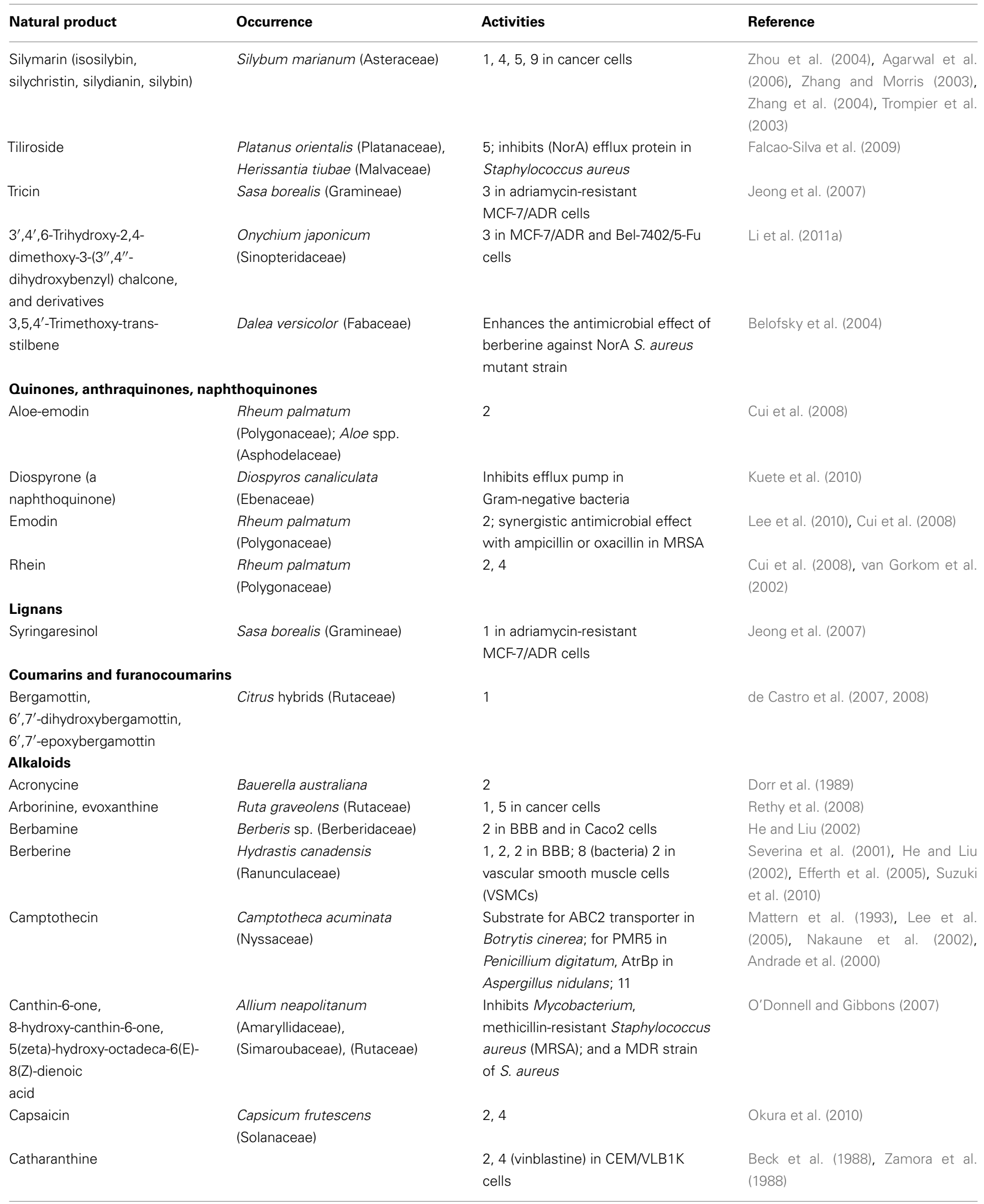

(Continued) 
Table 2 | Continued

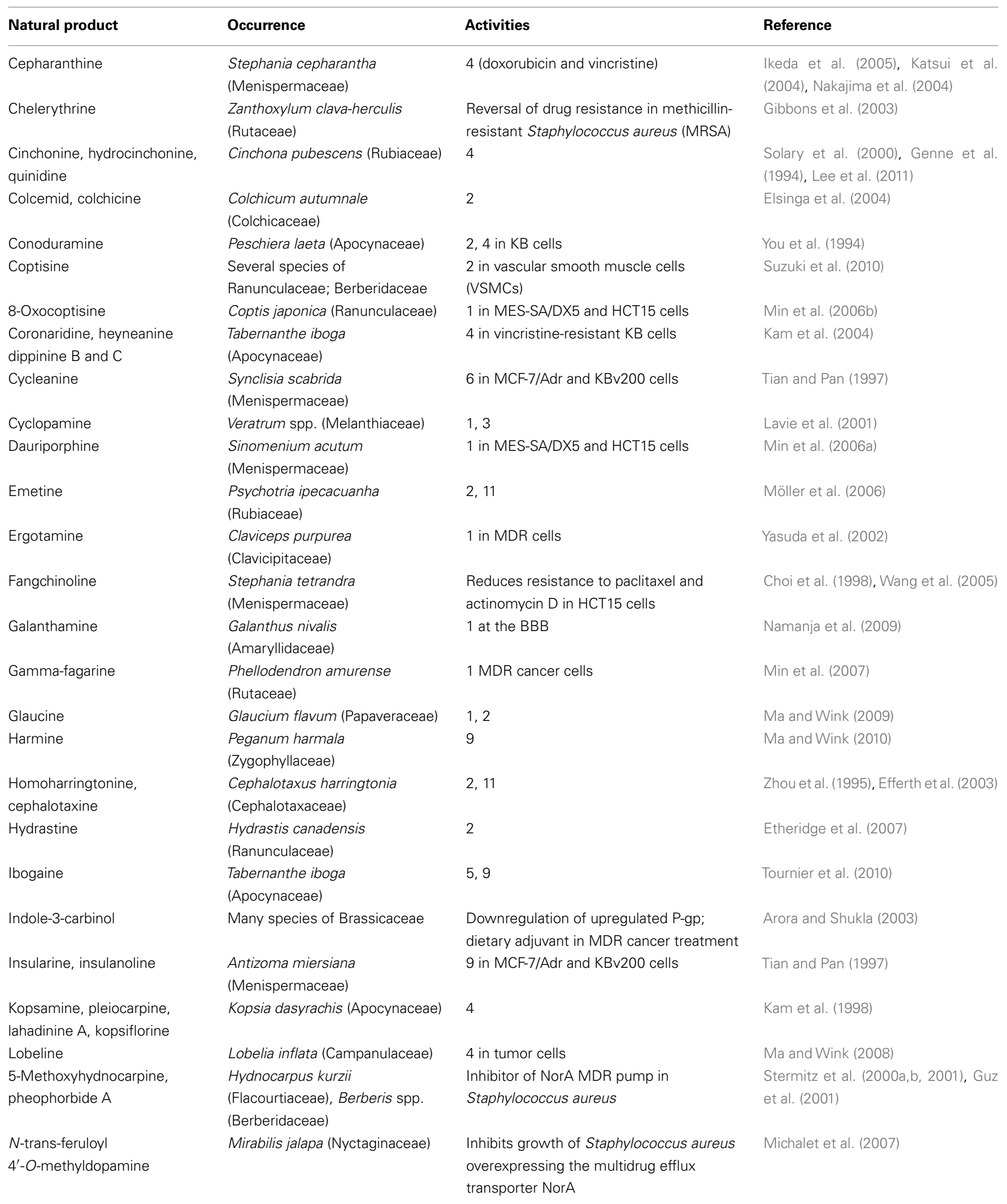

(Continued) 
Table 2 | Continued

\begin{tabular}{|c|c|c|c|}
\hline Natural product & Occurrence & Activities & Reference \\
\hline Paclitaxel & Taxus spp. (Taxaceae) & 2 & Distefano et al. (1997) \\
\hline Piperine & Piper nigrum (Piperaceae) & $\begin{array}{l}\text { 1, 2, 3, } 9 \text { in cancer cells; inhibition } \\
\text { of overexpressed mycobacterial } \\
\text { putative efflux protein (Rv1258c) }\end{array}$ & $\begin{array}{l}\text { Han et al. (2008), Bhardwaj et al. } \\
\text { (2002), Li et al. (2011 b), Sharma et al. } \\
\text { (2010) }\end{array}$ \\
\hline Quinine & Cinchona pubescens (Rubiaceae) & $2 ; 4$ & $\begin{array}{l}\text { Genne et al. (1994), Zamora et al. } \\
\text { (1988) }\end{array}$ \\
\hline Roemerine & $\begin{array}{l}\text { Annona senegalensis } \\
\text { (Annonaceae) }\end{array}$ & $2 ; 4$ & You et al. (1995) \\
\hline Rutaecarpine & Evodia rutaecarpa (Rutaceae) & $\begin{array}{l}6 \text { in p-gp overexpressing } \\
\text { CEM/ADR5000 cells }\end{array}$ & Lee et al. (1995), Adams et al. (2007) \\
\hline Sanguinarine & $\begin{array}{l}\text { Sanguinaria canadensis } \\
\text { (Papaveraceae) }\end{array}$ & 4 & $\begin{array}{l}\text { Ding et al. (2002), Weerasinghe et al. } \\
\text { (2006) }\end{array}$ \\
\hline $\begin{array}{l}\text { Stemocurtisine, } \\
\text { oxystemokerrine }\end{array}$ & $\begin{array}{l}\text { Stemona aphylla and S. burkillii } \\
\text { (Stemonaceae) }\end{array}$ & $\begin{array}{l}\text { P-gp modulator, enhance the } \\
\text { cytotoxicity of vinblastine, } \\
\text { paclitaxel, and doxorubicin in KB-V1 } \\
\text { cells }\end{array}$ & Chanmahasathien et al. (2011) \\
\hline Thaliblastine & Thalictrum spp. (Ranunculaceae) & $\begin{array}{l}\text { Reverses MDR by decreasing the } \\
\text { overexpression of P-gp in } \\
\text { MCF-7/Adr cells }\end{array}$ & $\begin{array}{l}\text { Chen and Waxman (1995), Chen } \\
\text { et al. (1993, 1996) }\end{array}$ \\
\hline Tomatidine & $\begin{array}{l}\text { Solanum lycopersicum } \\
\text { (Solanaceae) }\end{array}$ & 1,2 & Lavie et al. (2001) \\
\hline $\begin{array}{l}\text { Trisphaeridine, pretazettine, } \\
\text { 2-O-acetyllycorine, } \\
\text { risperidone }\end{array}$ & $\begin{array}{l}\text { Several species of } \\
\text { Amaryllidaceae }\end{array}$ & $\begin{array}{l}1 \text { and } 3 \text { in L5178 MDR mouse } \\
\text { lymphoma cells }\end{array}$ & Zupko et al. (2009) \\
\hline $\begin{array}{l}\text { Vasicine acetate, 2-acetyl } \\
\text { benzylamine }\end{array}$ & Adhatoda vasica. (Acanthaceae) & $\begin{array}{l}\text { Inhibit Mycobacterium tuberculosis } \\
\text { and a MDR strain }\end{array}$ & Ignacimuthu and Shanmugam (2010) \\
\hline Veralosinine, veranigrine & $\begin{array}{l}\text { Veratrum lobelianum, Veratrum } \\
\text { nigrum (Melanthiaceae) }\end{array}$ & 1 and 3 against doxorubicin & Ivanova et al. (2011) \\
\hline Vincristine, Vinblastine & $\begin{array}{l}\text { Catharanthus roseus } \\
\text { (Apocynaceae) }\end{array}$ & $2 ; 2$ in $\mathrm{BBB} ; 11$ & He and Liu (2002), Hu et al. (1995) \\
\hline Vindoline & & $\begin{array}{l}\text { 2; reversal of vinblastine resistance } \\
\text { in a MDR human leukemic cell line } \\
\text { and CEMNLB1K cells }\end{array}$ & Beck et al. (1988) \\
\hline
\end{tabular}


Table 2 | Continued

\begin{tabular}{|c|c|c|c|}
\hline Natural product & Occurrence & Activities & Reference \\
\hline Voacamine & $\begin{array}{l}\text { Peschiera laeta, Peschiera } \\
\text { fuchsiaefolia (Apocynaceae) }\end{array}$ & $\begin{array}{l}1,2 ; 2 \text { in } \mathrm{BBB} \text {; reversal of } \\
\text { vinblastine; and doxorubicin } \\
\text { resistance in MDR cancer cells by } \\
\text { binding to P-glycoprotein }\end{array}$ & $\begin{array}{l}\text { You et al. (1994), Meschini et al. } \\
(2003,2005)\end{array}$ \\
\hline Yohimbine & $\begin{array}{l}\text { Rauwolfia serpentina } \\
\text { (Apocynaceae) }\end{array}$ & $\begin{array}{l}\text { Reversal of vinblastine resistance in } \\
\text { a MDR human leukemic cell line } \\
\text { and CEMNLB } 100 \text { cells }\end{array}$ & $\begin{array}{l}\text { Zamora et al. (1988), Bhat et al. } \\
\text { (1995) }\end{array}$ \\
\hline
\end{tabular}

Activities: 1: inhibits p-gp; 2: p-gp substrate; 3: reversal of MDR; 4: reversal of p-gp mediated MDR; 5 : inhibition of MDR1 gene. 6: $p$-gp modulation in cancer cells; 7: induction of apoptosis; 8: substrate for ABC transporter; 9: blocks BCRP and increases in mitoxantrone accumulation; 10: MRP1 inhibitor; 11: induction of MDR overexpression.

Among the structurally heterogenous group of alkaloids, a large number of the more lipophilic substances from the classes of isoquinoline, protoberberine, quinoline, indole, monoterpene indole, and steroidal alkaloids (Table 2) can serve as substrates whereas the more polar alkaloids with a tropane, quinolizidine, piperidine, and pyrrolizidine skeleton do not bind to ABC transporters (Wink, 2007). Similar to the situation of terpenoids, the active alkaloids probably function as competitive inhibitors of $\mathrm{P}$ gp and BCRP in cancer cells, and NorA in bacteria and fungi (Table 2).

It is remarkable on the first sight that also quite a large number of more polar phenolic SM (phenolic acids, flavonoids, catechins, chalcones, xanthones, stilbenes, anthocyanins, tannins, anthraquinones, and naphthoquinones) inhibit P-gp, MRP1, BCRP, and OATP in cancer cells with MDR. Some of them can reverse MDR when given in combination with cytotoxic agents (Table 2). Bacteria and fungi appear to be sensitive as well (Guz et al., 2001; Falcao-Silva et al., 2009). Some of these phenolics are lipophilic enough to be competitive inhibitors of $\mathrm{ABC}$ transporters.

Polyphenols are exciting tethering compounds of proteins. They can effectively interact directly with proteins by forming hydrogen and ionic bonds with amino acid side chains. They can thus interfere with the 3D structure of proteins (conformation) and inhibit their activities (details in Wink, 2008b; Wink and Schimmer, 2010). We speculate therefore, that the inhibition seen in polyphenols is caused by a direct binding and complex formation (not necessarily the active side) of ABC transporters. Since many polyphenols have no or very low toxicity (e.g., many of them are ingredients of our food, such as flavonoids or tannins),

\section{REFERENCES}

Adams, M., Mahringer, A., Kunert, O., Fricker, G., Efferth, T., and Bauer, R. (2007). Cytotoxicity and p-glycoprotein modulating effects of quinolones and indoloquinazolines from the Chinese herb Evodia rutaecarpa. Planta Med. 73, 1554-1557.

Agarwal, R., Agarwal, C., Ichikawa, H., Singh, R. P., and Aggarwal, B. B. (2006). Anticancer potential of

they might be excellent candidates as reversal agents, both in chemotherapy and in agriculture.

We have focused on $A B C$ transporters in this review. But as mentioned above, resistance can be due to other mechanisms as well and is often multifactorial. Faria et al. (2011) and Kim et al. $(2007,2010)$ have successfully employed thymol (a phenolic monoterpene), salicyl aldehyde, and the alkaloid berberine to enhance the activity of fungicides in Candida, Aspergillus, Penicillium, and Cryptococcus. These experimental data can be regarded as a proof of concept that plant secondary products can be interesting candidates for chemosensitization (even if they not interfere with $\mathrm{ABC}$ transporters) of pathogenic fungi in agriculture and food technology to improve the fungicidal activity of certain fungicides.

\section{CONCLUSION}

This review summarizes the evidence that selected SM of plants can be interesting candidates to inhibit $\mathrm{ABC}$ transporters in MDR cancer cells or to chemosensitize pathogenic fungi and other microbes for treatment with antimicrobial agents. Whereas lipophilic terpenoids and alkaloids appear to be substrates of P-gp, MRP1, or BCRP and thus competitive inhibitors, the more polar phenolic compounds (flavonoids, tannins, quinones) can bind to the transporter proteins and inhibit their activity by disturbing protein conformation. A combination of a cytotoxic agent, antibiotic, or fungicide with a natural chemosensitizer (not necessarily an inhibitor of $\mathrm{ABC}$ transporters) might provide an interesting strategy to overcome MDR in cancer patients and to improve antibiotic or antifungal efficacy in medicine, agriculture, or food industry.

multiple flavonoids in combination alter the ABCG2-mediated tissue distribution of mitoxantrone in mice. Pharm. Res. 28, 1090-1099.

Andrade, A. C., Del Sorbo, G., Van Nistelrooy, J. G., and Waard, M. A. (2000). The ABC transporter AtrB from Aspergillus nidulans mediates resistance to all major classes of fungicides and some natural toxic compounds. Microbiology 146, 1987-1997.

Angelini, A., Di Ilio, C., Castellani, M. L., Conti, P., and Cuccurullo, F. (2010). Modulation of multidrug resistance p-glycoprotein activity by flavonoids and honokiol in human doxorubicin- resistant sarcoma cells (MES-SA/DX-5), implications for natural sedatives as chemosensitizing agents in cancer therapy. 
J. Biol. Regul. Homeost. Agents 24, 197-205.

Annereau, J. P., Szakács, G., Tucker, C. J., Arciello, A., Cardarelli, C., Collins, J., Grissom, S., Zeeberg, B. R., Reinhold, W., Weinstein, J. N., Pommier, Y., Paules, R. S., and Gottesman, M. M. (2004). Analysis of ATP-binding cassette transporter expression in drugselected cell lines by a microarray dedicated to multidrug resistance. Mol. Pharmacol. 66, 1397-1405.

Arora, A., and Shukla, Y. (2003). Modulation of vinca-alkaloid induced $\mathrm{P}$ glycoprotein expression by indole-3carbinol. Cancer Lett. 189, 167-173.

Beck, W. T., Cirtain, M. C., Glover, C. J., Felsted, R. L., and Safa, A. R. (1988). Effects of indole alkaloids on multidrug resistance and labeling of P-glycoprotein by a photoaffinity analog of vinblastine. Biochem. Biophys. Res. Commun. 153, 959-966.

Belofsky, G., Percivill, D., Lewis, K., Tegos, G. P., and Ekart, J. (2004). Phenolic metabolites of Dalea versicolor that enhance antibiotic activity against model pathogenic bacteria. J. Nat. Prod. 67, 481-484.

Berek, L., Szabo, D., Petri, I. B., Shoyama, Y., Lin, Y. H., and Molnar, J. (2001). Effects of naturally occurring glucosides, solasodine glucosides, ginsenosides and parishin derivatives on multidrug resistance of lymphoma cells and leukocyte functions. In vivo 15, 151-156.

Bhardwaj, R. K., Glaeser, H., Becquemont, L., Klotz, U., Gupta, S. K. and Fromm, M. F. (2002). Piperine, a major constituent of black pepper, inhibits human P-glycoprotein and CYP3A4. J. Pharmacol. Exp. Ther. 302, 645-650.

Bhat, U. G., Winter, M. A., Pearce, H. L., and Beck, W. T. (1995). A structurefunction relationship among reserpine and yohimbine analogues in their ability to increase expression of mdr1 and P-glycoprotein in a human colon carcinoma cell line. Mol. Pharmacol. 48, 682-689.

Brooks, T. A., Minderman, H., O’Loughlin, K. L., Pera, P., Ojima, I., Baer, M. R., and Bernacki, R. J. (2003). Taxane-based reversal agents modulate drug resistance mediated by P-glycoprotein, multidrug resistance protein, and breast cancer resistance protein. Mol. Cancer Ther. 2, 1195-1205.

Cavet, M. E., West, M., and Simmons, N. L. (1996). Transport and epithelial secretion of the cardiac glycoside, digoxin, by human intestinal epithelial (Caco-2) cells. Br. J. Pharmacol. 118, 1389-1396.
Chanmahasathien, W., Ampasavate, C., Greger, H., and Limtrakul, P. (2011). Stemona alkaloids, from traditional Thai medicine, increase chemosensitivity via P-glycoprotein-mediated multidrug resistance. Phytomedicine 18, 199-204.

Chauffert, B., Pelletier, H., Corda, C., Solary, E., Bedenne, L., Caillot, D., and Martin, F. (1990). Potential usefulness of quinine to circumvent the anthracycline resistance in clinical practice. Br. J. Cancer 62, 395-397.

Chen, G., Ramachandran, C., and Krishan, A. (1993). Thaliblastine, a plant alkaloid, circumvents multidrug resistance by direct binding to P-glycoprotein. Cancer Res. 53, 2544-2547.

Chen, G., Teicher, B. A., and Frei, E. (1996). Differential interactions of Pgp inhibitor thaliblastine with adriamycin, etoposide, taxol and anthrapyrazole CI941 in sensitive and multidrug-resistant human MCF-7 breast cancer cells. Anticancer Res. 16, 3499-3505.

Chen, G., and Waxman, D. J. (1995). Complete reversal by thaliblastine of 490-fold adriamycin resistance in multidrug-resistant (MDR) human breast cancer cells. Evidence that multiple biochemical changes in MDR cells need not correspond to multiple functional determinants for drug resistance. J. Pharmacol. Exp. Ther. 274, 1271-1277.

Chieli, E., Romiti, N., Rodeiro, I., and Garrido, G. (2010). In vitro modulation of $\mathrm{ABCB} 1 / \mathrm{P}$-glycoprotein expression by polyphenols from Mangifera indica. Chem. Biol. Interact. 186, 287-294.

Choi, C. H., Kang, G., and Min, Y. D. (2003). Reversal of P-glycoproteinmediated multidrug resistance by protopanaxatriol ginsenosides from Korean red ginseng. Planta Med. 69, 235-240.

Choi, S. U., Park, S. H., Kim, K. H., Choi, E. J., Kim, S., Park, W. K., Zhang, Y. H., Kim, H. S., Jung, N. P., and Lee, C. O. (1998). The bisbenzylisoquinoline alkaloids, tetrandine and fangchinoline, enhance the cytotoxicity of multidrug resistancerelated drugs via modulation of $\mathrm{P}$ glycoprotein. Anticancer Drugs 9, 255-261.

Chung, S. Y., Sung, M. K., Kim, N. H., Jang, J. O., Go, E. J., and Lee, H. J. (2005). Inhibition of P-glycoprotein by natural products in human breast cancer cells. Arch. Pharm. Res. 28, 823-828.

Chusri, S., Villanueva, I., Voravuthikunchai, S. P., and Davies, J. (2009).
Enhancing antibiotic activity, a strategy to control Acinetobacter infections. J. Antimicrob. Chemother. 64 1203-1211.

Conseil, G., Baubichon-Cortay, H., Dayan, G., Jault, J. M., Barron, D., and Di Pietro, A. (1998). Flavonoids, a class of modulators with bifunctional interactions at vicinal ATPand steroid-binding sites on mouse P-glycoprotein. Proc. Natl. Acad. Sci. U.S.A. 95, 9831-9836.

Cooray, H. C., Janvilisri, T., van Veen, H. W., Hladky, S. B., and Barrand, M. A. (2004). Interaction of the breast cancer resistance protein with plant polyphenols. Biochem. Biophys. Res. Commun. 317, 269-275.

Critchfield, J. W., Welsh, C. J., Phang, J. M., and Yeh, G. C. (1994). Modulation of adriamycin accumulation and efflux by flavonoids in HCT-15 colon cells. Activation of P-glycoprotein as a putative mechanism. Biochem. Pharmacol. 48, 1437-1445.

Cui, X. R., Tsukada, M., Suzuki, N., Shimamura, T., Gao, L., Koyanagi, J., Komada, F., and Saito, S. (2008). Comparison of the cytotoxic activities of naturally occurring hydroxyanthraquinones and hydroxynaphthoquinones. Eur. J. Med. Chem. 43, 1206-1215.

Dantzig, A. H., Law, K. L., Cao, J. and Starling, J. J. (2001). Reversal of multidrug resistance by the Pglycoprotein modulator, LY335979, from the bench to the clinic. Curr. Med. Chem. 8, 39-50.

Dantzig, A. H., Shepard, R. L., Cao, J. Law, K. L., Ehlhardt, W. J., Baughman, T. M., Bumol, T., and Starling, J. J. (1996). Reversal of P-glycoproteinmediated multidrug resistance by a potent cyclopropyldibenzosuberane modulator, LY335979. Cancer Res. 56, 4171-4179.

de Castro, W. V., Mertens-Talcott, S. Derendorf, H., and Butterweck, V. (2007). Grapefruit juice-drug interactions, grapefruit juice and its components inhibit P-glycoprotein (ABCB1) mediated transport of talinolol in Caco-2 cells. J. Pharm. Sci. 96, 2808-2817.

de Castro, W. V., Mertens-Talcott, S., Derendorf, H., and Butterweck, V. (2008). Effect of grapefruit juice, naringin, naringenin, and bergamottin on the intestinal carriermediated transport of talinolol in rats. J. Agric. Food Chem. 56, 4840-4845.

de Lannoy, I. A., and Silverman, M. (1992). The MDR1 gene product, Pglycoprotein, mediates the transport of the cardiac glycoside, digoxin.
Biochem. Biophys. Res. Commun. 189, 551-557.

de Wet, H., McIntosh, D. B., Conseil, G., Baubichon-Cortay, H., Krell, T., Jault, J. M., Daskiewicz, J. B., Barron, D., and Di Pietro, A. (2001). Sequence requirements of the ATP-binding site within the C-terminal nucleotide-binding domain of mouse P-glycoprotein, structure-activity relationships for flavonoid binding. Biochemistry 40, 10382-10391.

Ding, Z., Tang, S. C., Weerasinghe, P., Yang, X., Pater, A., and Liepins, A. (2002). The alkaloid sanguinarine is effective against multidrug resistance in human cervical cells via bimodal cell death. Biochem. Pharmacol. 63, 1415-1421.

Distefano, M., Scambia, G., Ferlini, C., Gaggini, C., De Vincenzo, R., Riva, A., Bombardelli, E., Ojima, I., Fattorossi, A., Panici, P. B., and Mancuso, S. (1997). Antiproliferative activity of a new class of taxanes (14beta-hydroxy-10deacetylbaccatin III derivatives) on multidrug-resistance-positive human cancer cells. Int. J. Cancer 72, 844-850.

Dorr, R. T., Liddil, J. D., Von Hoff, D. D., Soble, M., and Osborne, C. K. (1989). Antitumor activity and murine pharmacokinetics of parenteral acronycine. Cancer Res. 49, 340-344.

Duarte, N., Gyemant, N., Abreu, P. M., Molnar, J., and Ferreira, M. J. (2006). New macrocyclic lathyrane diterpenes, from Euphorbia lagascae, as inhibitors of multidrug resistance of tumour cells. Planta Med. 72, 162-168.

Duarte, N., Lage, H., Abrantes, M., and Ferreira, M. J. (2010). Phenolic compounds as selective antineoplasic agents against multidrugresistant human cancer cells. Planto Med. 76, 975-980.

Duarte, N., Ramalhete, C., Varga, A., Molnar, J., and Ferreira, M. J. (2009). Multidrug resistance modulation and apoptosis induction of cancer cells by terpenic compounds isolated from Euphorbia species. Anticancer Res. 29, 4467-4472.

Efferth, T., Chen, Z., Kaina, B., and Ag, W. (2005). Molecular determinants of response of tumor cells to berberine. Cancer Genomics Proteomics 2, 115-123.

Efferth, T., Sauerbrey, A., Halatsch, M. E., Ross, D. D., and Gebhart, E. (2003). Molecular modes of action of cephalotaxine and homoharringtonine from the coniferous tree Cephalotaxus hainanensis in human 
tumor cell lines. Naunyn Schmiedebergs Arch. Pharmacol. 367, 56-67.

El-Readi, M. Z., Hamdan, D., Farrag, N., El-Shazly, A., and Wink, M. (2010). Inhibition of P-glycoprotein activity by limonin and other secondary metabolites from Citrus species in human colon and leukaemia cell lines. Eur. J. Pharmacol. 626, 139-145.

Elsinga, P. H., Hendrikse, N. H., Bart, J., Vaalburg, W., and van Waarde, A. (2004). PET studies on P-glycoprotein function in the blood-brain barrier, how it affects uptake and binding of drugs within the CNS. Curr. Pharm. Des. 10, 1493-1503.

Etheridge, A. S., Black, S. R., Patel, P. R., So, J., and Mathews, J. M. (2007). An in vitro evaluation of cytochrome P450 inhibition and Pglycoprotein interaction with goldenseal, Ginkgo biloba, grape seed, milk thistle, and ginseng extracts and their constituents. Planta Med. 73, 731-741.

Falcao-Silva, V. S., Silva, D. A., Souza Mde, F., and Siqueira-Junior, J. P. (2009). Modulation of drug resistance in Staphylococcus aureus by a kaempferol glycoside from Herissantia tiubae (Malvaceae). Phytother. Res. 23, 1367-1370.

Faria, N. C. G., Kim, J. H., Goncalves, L., Martins, M., Chan, K. L., and, Campbell, B. (2011). Enhanced activity of antifungal drugs using natural phenolics against yeast strains of Candida and Cryptococcus. Lett. Appl. Micobiol. 5, 506-513.

Fernandes, J., Castilho, R. O., da Costa, M. R., Wagner-Souza, K., Coelho Kaplan, M. A., and Gattass, C. R. (2003). Pentacyclic triterpenes from Chrysobalanaceae species, cytotoxicity on multidrug resistant and sensitive leukemia cell lines. Cancer Lett. 190, 165-169.

Foster, B. C., Foster, M. S., Vandenhoek, S., Krantis, A., Budzinski, J. W., Arnason, J. T., Gallicano, K. D., and Choudri, S. (2001). An in vitro evaluation of human cytochrome P450 3A4 and P-glycoprotein inhibition by garlic. J. Pharm. Pharm. Sci. 4, 176-184.

Fu, L., Liang, Y., Deng, L., Ding, Y., Chen, L., Ye, Y., Yang, X., and Pan, Q. (2004). Characterization of tetrandrine, a potent inhibitor of P-glycoprotein-mediated multidrug resistance. Cancer Chemother. Pharmacol. 53, 349-356.

Fu, L. W., Zhang, Y. M., Liang, Y. J., Yang, X. P., and Pan, Q. C. (2002), The multidrug resistance of tumour cells was reversed by tetrandrine in vitro and in xenografts derived from human breast adenocarcinoma MCF-7/adr cells. Eur. J. Cancer 38, 418-426.

Genne, P., Dimanche-Boitrel, M. T., Mauvernay, R. Y., Gutierrez, G., Duchamp, O., Petit, J. M., Martin, F., and Chauffert, B. (1992). Cinchonine, a potent efflux inhibitor to circumvent anthracycline resistance in vivo. Cancer Res. 52, 2797-2801.

Genne, P., Duchamp, O., Solary, E., Pinard, D., Belon, J. P., DimancheBoitrel, M. T., and Chauffert, B. (1994). Comparative effects of quinine and cinchonine in reversing multidrug resistance on human leukemic cell line K562/ADM. Leukemia 8, 160-164.

Gibbons, S., Leimkugel, J., Oluwatuyi, M., and Heinrich, M. (2003). Activity of Zanthoxylum clava-herculis extracts against multi-drug resistant methicillin-resistant Staphylococcus aureus (mdr-MRSA). Phytother. Res. 17, 274-275.

Gibbons, S., and Udo, E. E. (2000). The effect of reserpine, a modulator of multidrug efflux pumps, on the in vitro activity of tetracycline against clinical isolates of methicillin resistant Staphylococcus aureus (MRSA) possessing the tet(K) determinant. Phytother. Res. 14, 139-140.

Gillet, J. P., Efferth, T., Steinbach, D., Hamels, J., de Longueville, F., Bertholet, V., and Remacle, J. (2004). Microarray-based detection of multidrug resistance in human tumor cells by expression profiling of ATPbinding cassette transporter genes. Cancer Res. 64, 8987-8993.

Gottesman, M. M. (2002). Mechanisms of cancer drug resistance. Annu. Rev. Med. 53, 615-627.

Guengerich, F. P. (2001). Uncommon P450-catalyzed reactions. Curr. Drug Metab. 2, 93-115.

Guo, X. L., Leng, P., Yang, Y., Yu, L. G., and Lou, H. X. (2008). Plagiochin $\mathrm{E}$, a botanic-derived phenolic compound, reverses fungal resistance to fluconazole relating to the efflux pump. J. Appl. Microbiol. 104, 831-838.

Guz, N. R., Stermitz, F. R., Johnson, J. B., Beeson, T. D., Willen, S., Hsiang, J., and Lewis, K. (2001). Flavonolignan and flavone inhibitors of a Staphylococcus aureus multidrug resistance pump, structure-activity relationships. J. Med. Chem. 44, 261-268.

Gyemant, N., Tanaka, M., Antus, S., Hohmann, J., Csuka, O., Mandoky, L., and Molnar, J. (2005). In vitro search for synergy between flavonoids and epirubicin on multidrug-resistant cancer cells. In vivo 19, 367-374.

Gyemant, N., Tanaka, M., Molnar, P. Deli, J., Mandoky, L., and Molnar, J. (2006), Reversal of multidrug resistance of cancer cells in vitro, modification of drug resistance by selected carotenoids. Anticancer Res. 26, 367-374.

Han, Y., Chin Tan, T. M., and Lim, L. Y. (2008). In vitro and in vivo evaluation of the effects of piperine on P-gp function and expression. Toxicol. Appl. Pharmacol. 230, 283-289.

He, L., and Liu, G. Q. (2002). Effects of various principles from Chinese herbal medicine on rhodamine 123 accumulation in brain capillary endothelial cells. Acta Pharmacol. Sin. 23, 591-596.

Hebestreit, P., and Melzig, M. (2003). Cytotoxic activity of the seeds from Agrostemma githago var. githago. Planta Med. 69, 921-925.

Hohmann, J., Molnar, J., Redei, D., Evanics, F., Forgo, P., Kalman, A., Argay, G., and Szabo, P. (2002). Discovery and biological evaluation of a new family of potent modulators of multidrug resistance, reversal of multidrug resistance of mouse lymphoma cells by new natural jatrophane diterpenoids isolated from Euphorbia species. J. Med. Chem. 45, 2425-2431.

Hou, X. L., Takahashi, K., Tanaka, K., Tougou, K., Qiu, F., Komatsu, K., and Azuma, J. (2008). Curcuma drugs and curcumin regulate the expression and function of $\mathrm{P}$ gp in Caco-2 cells in completely opposite ways. Int. J. Pharm. 358, 224-229.

Hu, X. F., Slater, A., Wall, D. M., Kantharidis, P., Parkin, J. D., Cowman, A., and Zalcberg, J. R. (1995). Rapid up-regulation of $\mathrm{mdr} 1$ expression by anthracyclines in a classical multidrug-resistant cell line. $B r . J$. Cancer 71, 931-936.

Hyafil, F., Vergely, C., Du Vignaud, P., and Grand-Perret, T. (1993). In vitro and in vivo reversal of multidrug resistance by GF120918, an acridonecarboxamide derivative. Cancer Res. 53, 4595-4602.

Ignacimuthu, S., and Shanmugam, N. (2010). Antimycobacterial activity of two natural alkaloids, vasicine acetate and 2-acetyl benzylamine, isolated from Indian shrub Adhatoda vasica Nees. leaves. J. Biosci. 35 , 565-570.

Ikeda, R., Che, X. F., Yamaguchi, T., Ushiyama, M., Zheng, C. L., Okumura, H., Takeda, Y., Shibayama, Y., Nakamura, K., and Jeung, H.
C. (2005). Cepharanthine potently enhances the sensitivity of anticancer agents in K562 cells. Cancer Sci. 96, 372-376.

Ingelman-Sundberg, M., and Gomez, A. (2010). The past, present and future of pharmacoepigenomics. Pharmacogenomics 11, 625-662.

Ivanova, A., Serly, J., Christov, V., Stamboliyska, B., and Molnar, J. (2011). Alkaloids derived from genus Veratrum and Peganum of Mongolian origin as multidrug resistance inhibitors of cancer cells. Fitoterapia $82,570-575$.

Ivanova, A., Serly, J., Dinchev, D., Ocsovszki, I., Kostova, I., and Molnar, J. (2009). Screening of some saponins and phenolic components of Tribulus terrestris and Smilax excelsa as MDR modulators. In vivo 23, 545-550.

Jeong, Y. H., Chung, S. Y., Han, A. R., Sung, M. K., Jang, D. S., Lee, J., Kwon, Y., Lee, H. J., and Seo, E. K. (2007). P-glycoprotein inhibitory activity of two phenolic compounds, (-)-syringaresinol and tricin from Sasa borealis. Chem. Biodivers. 4, 12-16.

Kam, T. S., Sim, K. M., Pang, H. S., Koyano, T., Hayashi, M., and Komiyama, K. (2004). Cytotoxic effects and reversal of multidrug resistance by ibogan and related indole alkaloids. Bioorg. Med. Chem. Lett. 14, 4487-4489.

Kam, T. S., Subramaniam, G., Sim, K. M., Yoganathan, K., Koyano, T., Toyoshima, M., Rho, M. C., Hayashi, M., and Komiyama, K. (1998). Reversal of multidrug resistance (MDR) by aspidofractininetype indole alkaloids. Bioorg. Med. Chem. Lett. 8, 2769-2772.

Kars, M. D., Iseri, O. D., Gunduz, U., and Molnar, J. (2008). Reversal of multidrug resistance by synthetic and natural compounds in drug-resistant MCF-7 cell lines. Chemotherapy 54, 194-200.

Kashiwada, Y., Nishimura, K., Kurimoto, S., and Takaishi, Y. (2011). New 29-nor-cycloartanes with a 3,4seco- and a novel 2,3-seco-structure from the leaves of Sinocalycanthus chinensis. Bioorg. Med. Chem. 19, 2790-2796.

Katsui, K., Kuroda, M., Wang, Y., Komatsu, M., Himei, K., Takemoto, M., Akaki, S., Asaumi, J., Kanazawa, S., and Hiraki, Y. (2004). Cepharanthine enhances adriamycin sensitivity by synergistically accelerating apoptosis for adriamycin-resistant osteosarcoma cell lines, SaOS2-AR and SaOS2 F-AR. Int. J. Oncol. 25, 47-56. 
Kim, J. H., Campbell, B. C., Mahoney, N., Chan, K. L., and Molyneux, R. J. (2010). Chemosensitization of aflatoxigenic fungi to antimycin $\mathrm{A}$ and strobilurin using salicylaldehyde, a volatile natural compound targeting cellular antioxidation system. Mycopathologia 171, 291-298.

Kim, J. H., Campbell, B. C., Mahoney, N., Chan, K. L., Molyneux, R. J., and May, G. (2007). Enhanced activity of strobilurin and fludioxonil by using berberine and phenolic compounds to target fungal antioxidative stress response. Lett. Appl. Microbiol. 45, 134-141.

Kitagawa, S., Nabekura, T., Nakamura, Y., Takahashi, T., and Kashiwada, Y. (2007). Inhibition of P-glycoprotein function by tannic acid and pentagalloylglucose. J. Pharm. Pharmacol. 59, 965-969.

Kolaczkowski, M., Kolaczowska, A., Luczynski, J., Witek, S., and Goffeau, A. (1998). In vivo characterization of the drug resistance profile of the major $\mathrm{ABC}$ transporters and other components of the yeast pleiotropic drug resistance network. Microb. Drug Resist. 4, 143-158.

Krishnamurthy, P., and Schuetz, J. D. (2006). Role of ABCG2/BCRP in biology and medicine. Annu. Rev. Pharmacol. Toxicol. 46, 381-410.

Kuete, V., Ngameni, B., Tangmouo, J. G., Bolla, J. M., Alibert-Franco, S., Ngadjui, B. T., and Pages, J. M. (2010). Efflux pumps are involved in the defense of Gram-negative bacteria against the natural products isobavachalcone and diospyrone. Antimicrob. Agents Chemother. 54, 1749-1752.

Kurimoto, S., Kashiwada, Y., Lee, K. H., and Takaishi, Y. (2011a). Triterpenes and a triterpene glucoside from Dysoxylum cumingianum. Phytochemistry 72, 2205-2211.

Kurimoto, S., Kashiwada, Y., MorrisNatschke, S. L., Lee, K. H., and Takaishi, Y. (2011b). Dyscusins A-C, three new steroids from the leaves of Dysoxylum cumingianum. Chem. Pharm. Bull. 59, 1303-1306.

Lavie, Y., Harel-Orbital, T., Gaffield, W., and Liscovitch, M. (2001). Inhibitory effect of steroidal alkaloids on drug transport and multidrug resistance in human cancer cells. Anticancer Res. 21, 1189-1194.

Lee, S. W., Hwang, B. Y., Kim, S. E., Kim, H. M., Kim, Y. H., Lee, K. S., Lee, J. J., and Ro, J.-S. (1995). Isolation of modulators for multidrug resistance from the fruits of Evodia officinalis. Korean J. Physiol. Pharmacol. 26, 344-348.
Lee, S. Y., Rhee, Y. H., Jeong, S. J., Lee, H. J., Jung, M. H., Kim, S. H., Lee, E. O., and Ahn, K. S. (2011). Hydrocinchonine, cinchonine, and qiuinidine potentiate paclitaxel-induced cytotoxicity and apoptosis via multidrug resistance reversal in MES-SA/DX5 uterine sarcoma cells. Environ. Toxicol. 26, 424-431.

Lee, Y.-J., Yamamoto, K., Hamamoto, H., Nakaune, R., and Hibi, T. (2005). A novel $\mathrm{ABC}$ transporter gene $\mathrm{ABC} 2$ involved in multidrug susceptibility but not pathogenicity in rice blast fungus, Magnaporthe grisea. Pestic. Biochem. Physiol. 81, 13-23.

Lee, Y. S., Kang, O. H., Choi, J. G., Oh, Y. C., Keum, J. H., Kim, S. B., Jeong, G. S., Kim, Y. C., Shin, D. W., and Kwon, D. Y. (2010). Synergistic effect of emodin in combination with ampicillin or oxacillin against methicillin-resistant Staphylococcus aureus. Pharm. Biol. 48, 1285-1290.

Leslie, E. M., Mao, Q., Oleschuk, C. J., Deeley, R. G., and Cole, S. P. (2001). Modulation of multidrug resistance protein 1 (MRP1/ABCC1) transport and ATPase activities by interaction with dietary flavonoids. Mol. Pharmacol. 59, 1171-1180.

Li, M. C., Yao, Z., Takaishi, Y., Tang, S. A., and Duan, H. Q. (2011a). Isolation of novel phenolic compounds with multidrug resistance (MDR) reversal properties from Onychium japonicum. Chem. Biodivers. 8, 1112-1120.

Li, S., Lei, Y., Jia, Y., Li, N., Wink, M., and Ma, Y. (2011b). Piperine, a piperidine alkaloid from Piper nigrum resensitizes P-gp, MRP1 and BCRP dependent multidrug resistant cancer cells. Phytomedicine 19, 83-87.

Limtrakul, P., Chearwae, W., Shukla, S., Phisalphong, C., and Ambudkar, S. V. (2007). Modulation of function of three $\mathrm{ABC}$ drug transporters, P-glycoprotein (ABCB1), mitoxantrone resistance protein (ABCG2) and multidrug resistance protein 1 (ABCC1) by tetrahydrocurcumin, a major metabolite of curcumin. Mol. Cell. Biochem. 296, 85-95.

Liu, D. F., Li, Y. P., Ou, T. M., Huang, S. L., Gu, L. Q., Huang, M., and Huang, Z. S. (2009). Synthesis and antimultidrug resistance evaluation of icariin and its derivatives. Bioorg. Med. Chem. Lett. 19, 4237-4240.

Loo, T. W., and Clarke, D. M. (2005). Recent progress in understanding the mechanism of P-glycoproteinmediated drug efflux. J. Membr. Biol. 206, 173-185.

Lu, J. J., Cai, Y. J., and Ding, J. (2012). The short-time treatment with curcumin sufficiently decreases cell viability, induces apoptosis and copper enhances these effects in multidrugresistant K562/A02 cells. Mol. Cell. Biochem. 360, 253-260.

Ma, Y., and Wink, M. (2008). Lobeline, a piperidine alkaloid from Lobelia can reverse P-gp dependent multidrug resistance in tumor cells. Phytomedicine 15, 754-758.

Ma, Y., and Wink, M. (2009). "Reversal of multidrug resistance (MDR) by the isoquinoline alkaloid glaucine," in Multiple Drug Resistance, eds A. Meszaros and G. Balogh (Hauppauge: Nova Science Publishers), 1-19.

Ma, Y., and Wink, M. (2010). The betacarboline alkaloid harmine inhibits $\mathrm{BCRP}$ and can reverse resistance to the anticancer drugs mitoxantrone and camptothecin. Phytother. Res. 24, 146-149.

Madureira, A. M., Spengler, G., Molnar, A., Varga, A., Molnar, J., Abreu, P. M., and Ferreira, M. J. (2004). Effect of cycloartanes on reversal of multidrug resistance and apoptosis induction on mouse lymphoma cells. Anticancer Res. 24, 859-864.

Mahringer, A., and Fricker, G. (2010). BCRP at the blood-brain barrier, genomic regulation by $17 \beta$ estradiol. Mol. Pharm. 7, 1835-1847.

Maliepaard, M., van Gastelen, M. A. Tohgo, A., Hausheer, F. H., van Waardenburg, R. C., de Jong, L. A., Pluim, D., Beijnen, J. H., and Schellens, J. H. (2001). Circumvention of breast cancer resistance protein (BCRP)-mediated resistance to camptothecins in vitro using non-substrate drugs or the BCRP inhibitor GF120918. Clin. Cancer Res. 7, 935-941.

Mao, Q., and Unadkat, J. D. (2005). Role of the breast cancer resistance protein (ABCG2) in drug transport. AAPS J. 7, E118-E133.

Markham, P. N., Westhaus, E., Klyachko, K., Johnson, M. E., and Neyfakh, A. A. (1999). Multiple novel inhibitors of the NorA multidrug transporter of Staphylococcus aureus. Antimicrob. Agents Chemother. 43, 2404-2408.

Martins, A., Vasas, A., Schelz, Z., Viveiros, M., Molnar, J., Hohmann, J., and Amaral, L. (2010). Constituents of Carpobrotus edulis inhibit P-glycoprotein of MDR1transfected mouse lymphoma cells. Anticancer Res. 30, 829-835.

Mattern, M. R., Hofmann, G. A., Polsky, R. M., Funk, L. R., McCabe, F. L., and Johnson, R. K. (1993). In vitro and in vivo effects of clinically important camptothecin analogues on multidrug-resistant cells. Oncol. Res. 5, 467-474.
Mei, Y., Qian, F., Wei, D., and Liu, J. (2004). Reversal of cancer multidrug resistance by green tea polyphenols. J. Pharm. Pharmacol. 56, 1307-1314. Meschini, S., Marra, M., Calcabrini, A., Federici, E., Galeffi, C., and Arancia, G. (2003). Voacamine, a bisindolic alkaloid from Peschiera fuchsiaefolia, enhances the cytotoxic effect of doxorubicin on multidrugresistant tumor cells. Int. J. Oncol. 23, 1505-1513.

Meschini, S., Marra, M., Condello, M., Calcabrini, A., Federici, E., Dupuis, M. L., Cianfriglia, M., and Arancia, G. (2005). Voacamine, an alkaloid extracted from Peschiera fuchsiaefolia, inhibits P-glycoprotein action in multidrug-resistant tumor cells. Int. J. Oncol. 27, 1597-1603.

Michalet, S., Cartier, G., David, B., Mariotte, A. M., Dijoux-Franca, M. G., Kaatz, G. W., Stavri, M., and Gibbons, S. (2007). Ncaffeoylphenalkylamide derivatives as bacterial efflux pump inhibitors. Bioorg. Med. Chem. Lett. 17, 1755-1758.

Min, Y. D., Choi, S. U., and Lee, K. R. (2006a). Aporphine alkaloids and their reversal activity of multidrug resistance (MDR) from the stems and rhizomes of Sinomenium acutum. Arch. Pharm. Res. 29, 627-632.

Min, Y. D., Yang, M. C., Lee, K. H., Kim, K. R., Choi, S. U., and Lee, K. R. (2006b). Protoberberine alkaloids and their reversal activity of P-gp expressed multidrug resistance (MDR) from the rhizome of Coptis japonica Makino. Arch. Pharm. Res. 29,757-761.

Min, Y. D., Kwon, H. C., Yang, M. C., Lee, K. H., Choi, S. U., and Lee, K. R. (2007). Isolation of limonoids and alkaloids from Phellodendron amurense and their multidrug resistance (MDR) reversal activity. Arch. Pharm. Res. 30, 58-63.

Möller, M., Weiss, J., and Wink, M. (2006). Reduction of cytotoxicity of the alkaloid emetine through Pglycoprotein (MDR1/ABCB1) in human Caco-2 cells and leukaemia cell lines. Planta Med. 72, 1121-1126.

Molnár, J., Engi, H., Gyémánt, N., Schelz, Z., Spengler, G., Ocsovski, I., Szücs, M., Hohmann, J., Szabo, M., and Tanács, L. (2008). "Multidrug resistance reversal in cancer cells by selected carotenoids, flavonoids and anthocyanins," in Bioactive Heterocycles VI, Vol. 15, ed. N. Motohashi (Berlin: Springer), 133-159. [Topics in Heterocyclic Chemistry].

Molnar, J., Gyemant, N., Mucsi, I., Molnar, A., Szabo, M., Kortvelyesi, 
T., Varga, A., Molnar, P., Toth, G. (2004). Modulation of multidrug resistance and apoptosis of cancer cells by selected carotenoids. In vivo 18, 237-244.

Najar, I. A., Sachin, B. S., Sharma, S. C., Satti, N. K., Suri, K. A., and Johri, R. K. (2010). Modulation of P-glycoprotein ATPase activity by some phytoconstituents. Phytother. Res. 24, 454-458.

Nakajima, A., Yamamoto, Y., Taura, K., Hata, K., Fukumoto, M., Uchinami, H., Yonezawa, K., and Yamaoka, Y. (2004). Beneficial effect of cepharanthine on overcoming drugresistance of hepatocellular carcinoma. Int. J. Oncol. 24, 635-645.

Nakaune, R. N., Hamamoto, H. H., Imada, J. I., Akutsu, K. A., and Hibi, T. H. (2002). A novel ABC transporter gene, is involved in multidrug resistance in the phytopathogenic fungus Penicillium digitatum. Mol. Genet. Genomics 267, 179-185.

Namanja, H. A., Emmert, D., Pires, M. M., Hrycyna, C. A., and Chmielewski, J. (2009). Inhibition of human P-glycoprotein transport and substrate binding using a galantamine dimer. Biochem. Biophys. Res. Commun. 388, 672-676.

Nielsen, D., and Skovsgaard, T. (1992). P-Glycoprotein as multidrug transporter - a critical-review of current multidrug resistant celllines. Biochim. Biophys. Acta 1139, 169-183.

Nissler, L., Gebhardt, R., and Berger, S. (2004). Flavonoid binding to a multi-drug-resistance transporter protein, an STD-NMR study. Anal. Bioanal. Chem. 379, 1045-1049.

Nooter, K., and Stoter, G. (1996). Molecular mechanisms of multidrug resistance in cancer chemotherapy. Pathol. Res. Pract. 192, 768-780.

O'Donnell, G., and Gibbons, S. (2007). Antibacterial activity of two canthin-6-one alkaloids from Allium neapolitanum. Phytother. Res. 21, 653-657.

Ofer, M., Langguth, P., and SpahnLangguth, H. (2006). Bidirectional membrane transport, simulations of transport inhibition in uptake studies explain data obtained with flavonoids. Eur. J. Pharm. Sci. 29, 251-258.

Ofer, M., Wolffram, S., Koggel, A., Spahn-Langguth, H., and Langguth, P. (2005). Modulation of drug transport by selected flavonoids: involvement of P-gp and OCT? Eur. J. Pharm. Sci. 25, 263-271.

Ohtani, H., Ikegawa, T., Honda, Y., Kohyama, N., Morimoto, S., Shoyama, Y., Juichi, M., Naito, M.,
Tsuruo, T., and Sawada, Y. (2007). Effects of various methoxyflavones on vincristine uptake and multidrug resistance to vincristine in $\mathrm{P}$-gpoverexpressing K562/ADM cells. Pharm. Res. 24, 1936-1943.

Okura, T., Ibe, M., Umegaki, K., Shinozuka, K., and Yamada, S. (2010). Effects of dietary ingredients on function and expression of $\mathrm{P}$ glycoprotein in human intestinal epithelial cells. Biol. Pharm. Bull.33, 255-259.

Ordway, D., Hohmann, J., Viveiros, M., Viveiros, A., Molnar, J., Leandro, C., Arroz, M. J., Gracio, M. A., and Amaral, L. (2003). Carpobrotus edulis methanol extract inhibits the MDR efflux pumps, enhances killing of phagocytosed $S$. aureus and promotes immune modulation. Phytother. Res. 17, 512-519.

Perez-Victoria, J. M., Chiquero, M. J., Conseil, G., Dayan, G., Di Pietro, A., Barron, D., Castanys, S., and Gamarro, F. (1999). Correlation between the affinity of flavonoids binding to the cytosolic site of Leishmania tropica multidrug transporter and their efficiency to revert parasite resistance to daunomycin. Biochemistry 38, 1736-1743.

Rethy, B., Hohmann, J., Minorics, R., Varga, A., Ocsovszki, I., Molnar, J., Juhasz, K., Falkay, G., and Zupko, I. (2008). Antitumour properties of acridone alkaloids on a murine lymphoma cell line. Anticancer Res. 28, 2737-2743.

Robert, J., and Jarry, C. (2003). Multidrug resistance reversal agents. $J$. Med. Chem. 46, 4805-4817.

Rocha Gda, G., Simoes, M., Lucio, K. A., Oliveira, R. R., Coelho Kaplan, M. A., and Gattass, C. R. (2007). Natural triterpenoids from Cecropia lyratiloba are cytotoxic to both sensitive and multidrug resistant leukemia cell lines. Bioorg. Med. Chem. 15, 7355-7360.

Rojas, R., Caviedes, L., Aponte, J. C., Vaisberg, A. J., Lewis, W. H., Lamas, G., Sarasara, C., Gilman, R. H., and Hammond, G. B. (2006). Aegicerin, the first oleanane triterpene with wide-ranging antimycobacterial activity, isolated from Clavija procera. J. Nat. Prod. 69, 845-846.

Scambia, G., Ranelletti, F. O., Panici, P. B., De Vincenzo, R., Bonanno, G. Ferrandina, G., Piantelli, M., Bussa, S., Rumi, C., and Cianfriglia, M. (1994). Quercetin potentiates the effect of adriamycin in a multidrugresistant MCF-7 human breastcancer cell line, P-glycoprotein as a possible target. Cancer Chemother. Pharmacol. 34, 459-464.
Schinkel, A. H., and Jonker, J. W. (2003). Mammalian drug efflux transporters of the ATP binding cassette (ABC) family, an overview. Adv. Drug Deliv. Rev. 55, 3-29.

Severina, I. I., Muntyan, M. S., Lewis, K., and Skulachev, V. P. (2001). Transfer of cationic antibacterial agents berberine, palmatine, and benzalkonium through bimolecular planar phospholipid film and Staphylococcus aureus membrane. IUBMB Life 52, 321-324.

Shapiro, A. B., and Ling, V. (1997). Effect of quercetin on Hoechst 33342 transport by purified and reconstituted P-glycoprotein. Biochem. Pharmacol. 53, 587-596.

Sharma, S., Kumar, M., Nargotra, A., Koul, S., and Khan, I. A. (2010). Piperine as an inhibitor of Rv1258c, a putative multidrug efflux pump of Mycobacterium tuberculosis. J. Antimicrob. Chemother. 65, 1694-1701.

Smith, E. C., Kaatz, G. W., Seo, S. M., Wareham, N., Williamson, E. M., and Gibbons, S. (2007). The phenolic diterpene totarol inhibits multidrug efflux pump activity in Staphylococcus aureus. Antimicrob. Agents Chemother. 51, 4480-4483.

Solary, E., Mannone, L., Moreau, D., Caillot, D., Casasnovas, R. O., Guy, H., Grandjean, M., Wolf, J. E., Andre, F., and Fenaux, P. (2000). Phase I study of cinchonine, a multidrug resistance reversing agent, combined with the CHVP regimen in relapsed and refractory lymphoproliferative syndromes. Leukemia 14, 2085-2094.

Steffens, J. J., Pell, E. J., and Tien, M. (1996). Mechanisms of fungicide resistance in phytopathogenic fungi. Curr. Opin. Biotechnol. 7, 348-355.

Steinbach, D., Sell, W., Voigt, A., Hermann, J., Zintl, F., and Sauerbrey, A. (2002). BCRP gene expression is associated with a poor response to remission induction therapy in childhood acute myeloid leukemia. Leukemia 16, 1443-1447.

Stermitz, F. R., Beeson, T. D., Mueller, P. J., Hsiang, J., and Lewis, K. (2001). Staphylococcus aureus MDR efflux pump inhibitors from a Berberis and a Mahonia (sensu strictu) species. Biochem. Syst. Ecol. 29, 793-798.

Stermitz, F. R., Lorenz, P., Tawara, J. N., Zenewicz, L. A., and Lewis, K. (2000a). Synergy in a medicinal plant, antimicrobial action of berberine potentiated by $5^{\prime}$ methoxyhydnocarpin, a multidrug pump inhibitor. Proc. Natl. Acad. Sci. U.S.A. 97, 1433-1437.
Stermitz, F. R., Tawara-Matsuda, J., Lorenz, P., Mueller, P., Zenewicz, L., and Lewis, K. (2000b), 5' Methoxyhydnocarpin-D and pheophorbide A, Berberis species components that potentiate berberine growth inhibition of resistant Staphylococcus aureus. J. Nat. Prod. 63, 1146-1149.

Stermitz, F. R., Scriven, L. N., Tegos, G., and Lewis, K. (2002). Two flavonols from Artemisia annua which potentiate the activity of berberine and norfloxacin against a resistant strain of Staphylococcus aureus. Planta Med. 68, 1140-1141.

Suttana, W., Mankhetkorn, S., Poompimon, W., Palagani, A., Zhokhov, S., Gerlo, S., Haegeman, G., and Berghe, W. V. (2010). Differential chemosensitization of P-glycoprotein overexpressing K562/Adr cells by withaferin A and Siamois polyphenols. Mol. Cancer 9, 99.

Suzuki, H., Tanabe, H., Mizukami, H., and Inoue, M. (2010). Selective regulation of multidrug resistance protein in vascular smooth muscle cells by the isoquinoline alkaloid coptisine. Biol. Pharm. Bull. 33, 677-682.

Tang, S., Bremner, P., Kortenkamp, A., Schlage, C., Gray, A. I., Gibbons, S., and Heinrich, M. (2003). Biflavonoids with cytotoxic and antibacterial activity from Ochna macrocalyx. Planta Med. 69, 247-253.

Taur, J. S., and Rodriguez-Proteau, R. (2008). Effects of dietary flavonoids on the transport of cimetidine via P-glycoprotein and cationic transporters in Caco-2 and LLC-PK1 cell models. Xenobiotica 38, 1536-1550.

Tian, H., and Pan, O. C. (1997). Modulation of multidrug resistance by three bisbenzyl-isoquinolines in comparison with verapamil. Zhongguo Yao Li Xue Bao 18, 455-458.

Tournier, N., Chevillard, L., Megarbane, B., Pirnay, S., Scherrmann, J. M. and Decleves, X. (2010). Interaction of drugs of abuse and maintenance treatments with human $\mathrm{P}$ glycoprotein (ABCB1) and breast cancer resistance protein (ABCG2). Int. J. Neuropsychopharmacol. 13, 905-915.

Trompier, D., Baubichon-Cortay, H., Chang, X. B., Maitrejean, M., Barron, D., Riordon, J. R., and Di Pietro, A. (2003). Multiple flavonoid-binding sites within multidrug resistance protein MRP1. Cell. Mol. Life Sci. 60, 2164-2177.

Twentyman, P. R., and Bleehen, N. M. (1991). Resistance modification by PSC-833, a 
novel non-immunosuppressive cyclosporin. Eur. J. Cancer 27, 1639-1642.

van der Kolk, D. M., Vellenga, E., Müller, M., and De Vries, E. G. E. (1999). Multidrug resistance protein MRP1, glutathione, and related enzymes their importance in acute myeloid leukemia. Adv. Exp. Med. Biol. 457, 187-198.

van Gorkom, B. A., Timmer-Bosscha, H., de Jong, S., van der Kolk, D. M., Kleibeuker, J. H., and de Vries, E. G. (2002). Cytotoxicity of rhein, the active metabolite of sennoside laxatives, is reduced by multidrug resistance-associated protein $1 . \mathrm{Br}$. J. Cancer 86, 1494-1500.

Versantvoort, C. H., Broxterman, H. J., Lankelma, J., Feller, N., and Pinedo, H. M. (1994). Competitive inhibition by genistein and ATP dependence of daunorubicin transport in intact MRP overexpressing human small cell lung cancer cells. Biochem. Pharmacol. 48, 1129-1136.

Versantvoort, C. H., Rhodes, T., and Twentyman, P. R. (1996). Acceleration of MRP-associated efflux of rhodamine 123 by genistein and related compounds. Br. J. Cancer 74, 1949-1954.

Wang, F. P., Wang, L., Yang, J. S., Nomura, M., and Miyamoto, K. (2005). Reversal of P-glycoproteindependent resistance to vinblastine by newly synthesized bisbenzylisoquinoline alkaloids in mouse leukemia P388 cells. Biol. Pharm. Bull. 28, 1979-1982.

Wang, L., Bai, L., Nagasawa, T., Hasegawa, T., Yang, X., Sakai, J., Bai, Y., Kataoka, T., Oka, S., and Hirose, K. (2008). Bioactive triterpene saponins from the roots of Phytolacca americana. J. Nat. Prod. 71, 35-40.

Watanabe, T., Tsuge, H., Oh-Hara, T., Naito, M., and Tsuruo, T. (1995). Comparative study on reversal efficacy of SDZ PSC 833, cyclosporin $A$ and verapamil on multidrug resistance in vitro and in vivo. Acta Oncol 34, 235-241.

Weerasinghe, P., Hallock, S., Tang, S. C., Trump, B., and Liepins, A. (2006). Sanguinarine overcomes Pglycoprotein-mediated multidrugresistance via induction of apoptosis and oncosis in CEM-VLB 1000 cells. Exp. Toxicol. Pathol. 58, 21-30.

Wei, D., Mei, Y., and Liu, J. (2003). Quantification of doxorubicin and validation of reversal effect of tea polyphenols on multidrug resistance in human carcinoma cells. Biotechnol. Lett. 25, 291-294.
Wesolowska, O., Hendrich, A. B., Laniapietrzak, B., Wisniewski, J., Molnar, J., Ocsovszki, I., and Michalak, K. (2009). Perturbation of the lipid phase of a membrane is not involved in the modulation of MRP1 transport activity by flavonoids. Cell. Mol. Biol. Lett. 14, 199-221.

Wesolowska, O., Wisniewski, J., Duarte, N., Ferreira, M. J., and Michalak, K. (2007). Inhibition of MRP1 transport activity by phenolic and terpenic compounds isolated from Euphorbia species. Anticancer Res. 27, 4127-4133.

Wijnholds, J., deLange, E. C., Scheffer, G. L., van den Berg, D. J., Mol, C. A., van derValk, M., Schinkel, A. H., Scheper, R. J., Breimer, D. D., and Borst, P. (2000). Multidrug resistance protein 1 protects the choroid plexus epithelium and contributes to the bloodcerebrospinal fluid barrier. J. Clin. Invest. 105, 279-285.

Wink, M. (1988). Plant breeding: importance of plant secondary metabolites for protection against pathogens and herbivores. Theor. Appl. Genet. 75, 225-233.

Wink, M. (1993). Allelochemical properties and the raison d'être of alkaloids. Alkaloids Chem. Biol. 43, 1-118.

Wink, M. (2000). Interference of alkaloids with neuroreceptors and ion channels. Nat. Prod. Res. 21, 3-129.

Wink, M. (2003). Evolution of secondary metabolites from an ecological and molecular phylogenetic perspective. Phytochemistry 64, 3-19.

Wink, M. (2007). Molecular modes of action of cytotoxic alkaloids- from DNA intercalation, spindle poisoning, topoisomerase inhibition to apoptosis and multiple drug resistance. Alkaloids Chem. Biol. 64, 1-48.

Wink, M. (2008a). Plant secondary metabolism: diversity, function and its evolution. Nat. Prod. Commun. 3, 1205-1216.

Wink, M. (2008b). Evolutionary advantage and molecular modes of action of multi-component mixtures used in phytomedicine. Curr. Drug Metab. 9, 996-1009.

Wink, M. (2010a). Functions and Biotechnology of Plant Secondary Metabolites - Annual Plant Reviews, Vol. 39. Chichester: Wiley-Blackwell. Wink, M. (2010b). Biochemistry of Plant Secondary Metabolism - Annual Plant Reviews, Vol. 40. Chichester: Wiley-Blackwell.

Wink, M., and Schimmer, O. (2010). "Molecular modes of action of defensive secondary metabolites," in Functions and Biotechnology of Plant Secondary Metabolites, Vol. 39, ed. M.
Wink (Chichester: Wiley-Blackwell), 21-161.

Xu, W. L., Shen, H. L., Ao, Z. F., Chen, B. A., Xia, W., Gao, F., and Zhang, Y. N. (2006). Combination of tetrandrine as a potential-reversing agent with daunorubicin, etoposide and cytarabine for the treatment of refractory and relapsed acute myelogenous leukemia. Leuk. Res. 30, 407-413.

Yasuda, K., Lan, L. B., Sanglard, D., Furuya, K., Schuetz, J. D., and Schuetz, E. G. (2002). Interaction of cytochrome P450 3A inhibitors with P-glycoprotein. J. Pharmacol. Exp. Ther. 303, 323-332.

Ye, J., Zheng, Y., and Liu, D. (2009). Reversal effect and its mechanism of ampelopsin on multidrug resistance in K562/ADR cells. Zhongguo Zhong Yao Za Zhi 34, 761-765.

Yoo, H. H., Lee, M., Chung, H. J., Lee, S. K., and Kim, D.-H. (2007). Effects of diosmin, a flavonoid glycoside in citrus fruits, on P-glycoproteinmediated drug efflux in human intestinal Caco-2 cells. J. Agric. Food Chem. 55, 7620-7625.

Yoshida, N., Takagi, A., Kitazawa, H., Kawakami, J., and Adachi, I. (2005). Inhibition of P-glycoproteinmediated transport by extracts of and monoterpenoids contained in Zanthoxyli fructus. Toxicol. Appl. Pharmacol. 209, 167-173.

You, G., and Morris, M. E. (2007). Drug Transporters- Molecular Characterization and Role in Drug Disposition. Hoboken, NJ: Wiley-Interscience.

You, M., Ma, X., Mukherjee, R., Farnsworth, N. R., Cordell, G A., Kinghorn, A. D., and Pezzuto, J. M. (1994). Indole alkaloids from Peschiera laeta that enhance vinblastine-mediated cytotoxicity with multidrug-resistant cells. J. Nat. Prod. 57, 1517-1522.

You, M., Wickramaratne, D. B., Silva, G. L., Chai, H., Chagwedera, T. E., Farnsworth, N. R., Cordell, G. A., Kinghorn, A. D., and Pezzuto, J. M. (1995). (-)-Roemerine, an aporphine alkaloid from Annona senegalensis that reverses the multidrugresistance phenotype with cultured cells. J. Nat. Prod. 58, 598-604.

Zamora, J. M., Pearce, H. L., and Beck, W. T. (1988). Physical-chemical properties shared by compounds that modulate multidrug resistance in human leukemic cells. Mol. Pharmacol. 33, 454-462.

Zhang, S., and Morris, M. E. (2003). Effects of the flavonoids biochanin A, morin, phloretin, and silymarin on P-glycoprotein-mediated transport. J. Pharmacol. Exp. Ther. 304 1258-1267.
Zhang, S., Yang, X., and Morris, M. E. (2004). Flavonoids are inhibitors of breast cancer resistance protein (ABCG2)-mediated transport. $\mathrm{Mol}$ Pharmacol. 65, 1208-1216.

Zhao, M., Bai, L., Wang, L., Toki, A., Hasegawa, T., Kikuchi, M., Abe, M., Sakai, J., Hasegawa, R., and Bai, Y. (2007). Bioactive cardenolides from the stems and twigs of Nerium oleander. J. Nat. Prod. 70, 1098-1103.

Zhou, D. C., Zittoun, R., and Marie, J. P. (1995). Homoharringtonine, an effective new natural product in cancer chemotherapy. Bull. Cancer 82, 987-995.

Zhou, S., Lim, L. Y., and Chowbay, B. (2004). Herbal modulation of Pglycoprotein. Drug Metab. Rev. 36, 57-104.

Zhu, A., Wang, X., and Guo, Z. (2001). Study of tea polyphenol as a reversal agent for carcinoma cell lines' multidrug resistance (study of TP as a MDR reversal agent). Nucl. $\mathrm{Med}$. Biol. 28, 735-740.

Zhu, X., Sui, M., and Fan, W. (2005). In vitro and in vivo characterizations of tetrandrine on the reversal of P-glycoprotein-mediated drug resistance to paclitaxel. Anticancer Res. 25, 1953-1962.

Zupko, I., Rethy, B., Hohmann, J., Molnar, J., Ocsovszki, I., and Falkay, G. (2009). Antitumor activity of alkaloids derived from Amaryllidaceae species. In vivo 23, 41-48.

Conflict of Interest Statement: The authors declare that the research was conducted in the absence of any commercial or financial relationships that could be construed as a potential conflict of interest.

Received: 12 January 2012; accepted: 19 March 2012; published online: 23 April 2012.

Citation: Wink M, Ashour ML and ElReadi MZ (2012) Secondary metabolites from plants inhibiting $A B C$ transporters and reversing resistance of cancer cells and microbes to cytotoxic and antimicrobial agents. Front. Microbio. 3:130. doi: 10.3389/fmicb.2012.00130

This article was submitted to Frontiers in Fungi and Their Interactions, a specialty of Frontiers in Microbiology.

Copyright (c) 2012 Wink, Ashour and El-Readi. This is an open-access article distributed under the terms of the Creative Commons Attribution Non Commercial License, which permits noncommercial use, distribution, and reproduction in other forums, provided the original authors and source are credited. 